Research Paper

\title{
A Multifactoral Analysis of 1452 Patients for Smoking Sensation. An Outpatient Lab Experience
}

\author{
Theodora Tsiouda1,2, Paul Zarogoulidis ${ }^{2}$, Dimitris Petridis ${ }^{3}$, Nikolaos Pezirkianidis ${ }^{4}$, Ioannis Kioumis ${ }^{2}$, \\ Lonny Yarmus ${ }^{5}$, Haidong Huang, Qiang Li 6 , Wolfgang Hohenforst-Schmidt ${ }^{7}$, Konstantinos Porpodis², \\ Dionysios Spyratos², Kosmas Tsakiridis², Georgia Pitsiou², Theodoros Kontakiotis², Paraskevi Argy- \\ ropoulou², George Kyriazis², Konstantinos Zarogoulidis² \\ 1. Internal Medicine Department, “'Theageneio“ Anticancer Hospital, Thessaloniki, Greece. \\ 2. Pulmonary Department-Oncology Unit, ' 'G. Papanikolaou” General Hospital, Aristotle University of Thessaloniki, Thessaloniki, Greece. \\ 3. Department of Food Technology, School of Food Technology and Nutrition, Alexander Technological Educational Institute, Thessaloniki, Greece. \\ 4. Surgery Department, Private Cabinet, Serres, Greece. \\ 5. Division of Pulmonary and Critical Care Medicine, Johns Hopkins University, Baltimore, U.S.A. \\ 6. Department of Respiratory Diseases Shanghai Hospital, II Military University Hospital, Shanghai, China. \\ 7. II Medical Department, General Hospital of Coburg, University of Wuerzburg, Coburg, Germany.
}

$\triangle$ Corresponding author: Paul Zarogoulidis, Pulmonary Department-Oncology Unit, “'G. Papanikolaou” General Hospital, Aristotle University of Thessaloniki, Thessaloniki, Greece. Tel: +306977271974 Fax: +302310992433 e-mail: pzarog@hotmail.com.

(c) Ivyspring International Publisher. This is an open-access article distributed under the terms of the Creative Commons License (http://creativecommons.org/ licenses/by-nc-nd/3.0/). Reproduction is permitted for personal, noncommercial use, provided that the article is in whole, unmodified, and properly cited.

Received: 2014.04.10; Accepted: 2014.04.19; Published: 2014.05.10

\begin{abstract}
Smoking habit is held responsible for several respiratory and metabolic diseases. Data from 1452 patients were recorded from our outpatient laboratory. The following parameters were recorded within several follow ups of our patients; smoking habit, respiratory functions, smoking cessation questionnaires, and administered drugs. The treatment administered to smokers throughout the period of inspection seems to also have a significant effect on dependence. In fact, varelicline causes a $50 \%$ reduction in smoking dependence in regards to nicotine substitutes (odds ratio: 0.48 $(0.3 \mathrm{I}-0,74), \mathrm{p}=0.00 \mathrm{I})$ so displaying a substantial preponderance on the choice to fight smoking dependence.
\end{abstract}

Key words: smoking sensation, COPD, Asthma, CAD.

\section{Introduction}

Lung cancer still remains the main cause of cancer death among males after prostate cancer and the second main cancer among females after breast cancer [1]. Lung cancer can be distinguished between non-small cell lung cancer (NSCLC) and small cell lung cancer (SCLC). Early detection still remains a major issue since symptoms are usually observed when disease is advanced [2-4]. Patients usually have a number of symptoms such as; cough, shortness of breath activity, hemoptysis, repeated infections such as bronchitis and pneumonia, and pain or aching in your shoulder (Pancoast tumors). These symptoms are usually not given the proper assessment by the patients and therefore diagnosis is delayed. Stage at diagnosis is very important for treatment. Although pulmonary physicians and radiologists have state of the art equipment for biopsy and evaluation of solitary nodules [5-8], we still do not have an algorithm for early screening. We usually recommend CT of the thorax screening to patients of 55-74 years of age and with at least 30 pack years. Lung cancer diagnosis is currently made with imaging techniques and biopsy/cytology techniques. Imaging techniques are x-ray of the thorax, computed tomography scan of the thorax and PET-CT scan of the thorax. Cytology examination from pleural effusion or bronchoalveolar lavage and tissue biopsy will provide the exact subtype of lung cancer. Usually for the follow up of 
treatment the RECIST criteria are being used [9]. In order to obtain samples for diagnosis a number of tools and methodologies are available such as; bronchoscopy, endobronchial ultrasound (EBUS), medical thoracoscopy, fluoroscopy [10]. Regarding treatment, surgery is an option for early stage disease and chemotherapy and or radiotherapy for advanced stage [11-19]. Currently, molecular targeted treatment is an option for several patients and therefore screening for certain genetic mutations are absolutely necessary since trial outcomes have presented superiority [17]. In specific, tumors that have the anaplastic lymphoma kinase (ALK) gene change, crizotinib (Xalkori) is often the first treatment. For people whose cancers have certain changes in the epidermal growth factor receptor mutation (EGFR) gene, either of the anti-EGFR drugs erlotinib (Tarceva), Iressa or afatinib (Gilotrif) may be used without chemotherapy as the first treatment. Moreover; the extent of lymph node involvement and whether or not cancer cells are found at the edges of the removed tissues are important factors when planning the next step of treatment (CT-thorax/PET-CT thorax evidence and endobronchail ultrasound biopsy). In certain cases, chemotherapy (often along with radiation) may be recommend before surgery to try to shrink the tumor to make the operation easier. After surgery, chemotherapy (with or without radiation therapy) is usually given to try to destroy any cancer cells that might have been left behind.

Furthermore, we should not forget the side-effects of standard i.v administration the major one being myelosuppression [20]. On the other hand tyrosine kinase inhibitors (TKIs) have as a side effect rash which in mild manifestation can be controlled with moisturizing cremes and in more severe cases of skin infection the addition of antibiotics is necessary. The severity of the rash has been also associated with the effectiveness of TKIs as treatment [21].

Moreover; chronic obstructive pulmonary disease (COPD) is characterized by chronic inflammation and progressive destruction of lung parenchyma. Despite the pharmaceutical or interventional treatment modalities the loss of lung tissue and remodeling still continues $[22,23]$. The pathogenesis of COPD involves the alveoli $(<2 \mathrm{~mm})$ and the tissue beyond. The airflow parameters change due to the loss of elastic lung recoil pressure. Moreover; endothelial dysfunction and vascular remodeling is initiated by vascular endothelial growth factor (VEGF)-mediated apoptosis [24]. It has been observed that inflammatory response caused by exposure to several environmental factors such as; cigarette smoking and air pollution is based on proteolytic and oxidant stress [25, 26]. The inflammatory response and damage is enhanced with exacerbations. Despite the removal of the trigger factor the inflammatory cells (neutrophils, macrophages and lymphocytes) still remain in large numbers within the respiratory airways and continue the inflammation [27-29]. Smoking sensation is absolutely necessary for the human health since smoking affects not only the smoker, but also the people in the surrounding environment [30]. Several pharmacological and non-pharmacological modalities are being currently being used [31]. Currently nicotine replacement therapy (oral, patch and inhaler), Zyban (bupropion) and Champix (varenicline) are used as drug therapy and acupuncture, hypnosis and electronic cigarettes as alternative methods. Future studies must be carried out to determine the effectiveness of varenicline (Chantix) treatment compared with each of these established smoking cessation therapies. The recent studies also showed that varenicline (Chantix) was relatively well-tolerated by the smokers who took part in the study. Nausea was the most common side effect of the drug, and other side effects included headache, vomiting, flatulence (gas), insomnia, abnormal dreams, and changes in taste perception. The FDA-approved course of treatment with varenicline (Chantix) is twelve weeks. If smoking cessation is successful during the initial twelve-week treatment, a further twelve-week treatment may be given to increase the probability of long-term cessation of smoking.

Additionally, several genes have been implicating in smoking initiation in young patients [32]. Biomarkers on the other hand have been also identified which are associated with smoking initiation and smoking sensation [33]. Close to the different genes and biomarkers new scales for smoking sensation have been identified and modified according to different populations [34]. In our current retrospective study we included data from 1452 patients from our outpatient cabinet and present our experience from our efforts for smoking sensation.

\section{Materials and methods}

\section{Statistical analysis}

The antismoking research was based on measurements concerning the historical profile and pathogenic conditions of 1452 volunteers who admitted the outpatient lab of smoking sensation. The sample was treated either as a whole or sub-grouped to patients suffering from disease. In particular, the research was oriented to the assessment of the pagothenic and social variables/factors effect on the degree of dependence on smoking following the Fagerstrom's scale which ranges between 0 (no dependence) to 9 (strong dependence). Moreover, the 
readiness on quitting smoking was also evaluated using a 1-19 point's scale of increasing magnitude.

Data was treated using, apart from descriptive and cross-tabulation statistics, some elaborate techniques each with particular importance:

A) A Multiple Correspondence analysis in order to reveal personalized relationships between smokers on the will to quit smoking at four consecutive periods of antismoking surveillance.

B) The Fagerstrom's dependence was divided to three levels of increasing order: low (1-3), moderate (4-7) and strong (8-10) dependence. Then the new order variable was regressed as dependent against all the independent variables of the study (social and diseases). This technique, known multiple ordinal regressions, can determine the most important variables that influence, in terms of odds ratio, the smoking dependence in joint with the technique of backward removal of non-significant variables.

C) The variables Fagerstrom's dependence and readiness on smoking stoppage were treated as quantitative dependent against all the aforesaid variables, the latter considered as factors this time, by employing the Analysis Of Variance. Means calculated from statistically significant factors were examined for potential differences between factors levels by comparing their 95\% confidence intervals based on the pooled standard error of ANOVA. Intervals that do not overlap represent means that differ significantly each other.

D) Potential combined effects among the social and disease factors on Fagerstrom's dependence were checked by adopting the tree regression deployed by the CHAID (Chi-squared Automatic Interaction Detector) classification and seen as dendrogram of cascading effects. The reliability of the technique was explored by the risk estimate a quantity that measures the magnitude of variance which should be minimal. The predicted validity was checked by using a 10-fold cross validation procedure which also produces a measure of variance. The values of both variances should converge in order to produce reliable results. In all statistical analyses the 0.05 probability level of significance was chosen as level of reference.

\section{Results}

Simple descriptive statistics of social and historical variables are shown in Table 1 . The gender is equally encountered in the sample of smokers (1:1, $\left.790: 751, x^{2}=0,937, p=0,333\right)$, the age-group $46-65$ prevails in the sample (41.4\%) followed by the ages 36-45 $(\mathrm{N}=505,32,9 \%)$ and $26-35(\mathrm{~N}=279,18,2 \%)$. Smokers $>65 \mathrm{y} / \mathrm{o}$ and young people 18-25 y/o show minor contribution (3.8\% and $3.7 \%$ respectively).
Table I. Cross-tabulated statistics on the social and historical variables of the study.

\begin{tabular}{|c|c|c|}
\hline & $\mathrm{N}$ & $\%$ \\
\hline \multicolumn{3}{|l|}{ GENDER } \\
\hline Men & 790 & 51,3 \\
\hline Women & 751 & 48,7 \\
\hline Age Group & $\mathrm{N}$ & $\%$ \\
\hline $18-25$ & 56 & 3,7 \\
\hline $26-35$ & 279 & 18,2 \\
\hline $36-45$ & 505 & 32,9 \\
\hline $46-65$ & 634 & 41,4 \\
\hline$>65$ & 59 & 3,8 \\
\hline \multicolumn{3}{|l|}{ OCCUPATION } \\
\hline Jobless & 50 & 3,3 \\
\hline Blue colar & 286 & 18,6 \\
\hline White colar & 78 & 5,1 \\
\hline Ordinary jobs & 774 & 50,4 \\
\hline Housekeeper & 163 & 10,6 \\
\hline Pensioner & 167 & 10,9 \\
\hline Student & 19 & 1,2 \\
\hline \multicolumn{3}{|l|}{ INFORMATION } \\
\hline Mass media & 298 & 19,4 \\
\hline Surrounding environment & 1242 & 80,6 \\
\hline \multicolumn{3}{|l|}{ FAGERSTROM'S } \\
\hline \multicolumn{3}{|l|}{ CLASSES } \\
\hline $0-3$ & 144 & 9,6 \\
\hline $4-7$ & 758 & 50,7 \\
\hline $8-10$ & 592 & 39,6 \\
\hline \multicolumn{3}{|c|}{ ATTEMPT TO QUIT SMOKING } \\
\hline 1 & 328 & 21,3 \\
\hline 2 & 31 & 2,0 \\
\hline 3 & 14 & 0,9 \\
\hline none & 1167 & 75,8 \\
\hline \multicolumn{3}{|l|}{ TREATMENT } \\
\hline TTS substitutes & 99 & 6,6 \\
\hline Varelicline & 1405 & 93,4 \\
\hline
\end{tabular}

The distribution of smokers' occupations reveals a $50.4 \%$ of skilled people (774), $18,6 \%$ of unschooled (286), housekeepers and pensioners contribute $21,5 \%$, jobless people 3,3\% and students 1,2\%.

Social media contributed $19.4 \%$ to the message of the outpatient lab activities to smokers and $80.6 \%$ the surrounding environment (family, friends and relatives). Smokers who never tried to quit smoking constitute $75.8 \%$ of the sample, those who tried once 21,3 , twice 2,0\% and those who attempted three times 0,9\% (14 people).

Smokers were arranged numerically to the three rank levels of Fagerstrom's dependence on nicotine effect: low effect $(0-3,144$ individuals), moderate (4-7, 758 smokers) and strong effect $(8-10,592)$.

Varelicline or TSS substitutes were the two drugs administered, according to recommendations by the outpatient lab, to the smokers during the full period of inspection $(\mathrm{N}=1405,93.4 \%$ and $\mathrm{N}=99,6.6 \%$ respectively) to fight the addiction to nicotine.

The volunteers were examined, additionally, for pathological findings and it was well found that for 657 individuals $(42,6 \%)$ one clinical or biochemical problem at least was identified (Table 2). Thus, 13,7\% of the endangered people were recorded as patients of 
Chronic obstructive pulmonary, the $1^{\text {st }}$ stage dominating at $8,6 \%$. The arterial hypertension covers the 10,4 of the ail people whereas some other diseases (diabetes mellitus, hyperlipidemia, peptic disorders, hypothyroidism, psycho-neurotic problems) take up each $4-5 \%$ and totaling $25,6 \%$.

Table 2. Numerical and percentage distribution of the various pathologic conditions encountered in the study.

\begin{tabular}{lll}
\hline & N & $\%$ \\
\hline DISEASE & 657 & 42,6 \\
COPD & 211 & 13,7 \\
Stage 1 & 133 & 8,6 \\
Stage 2 & 38 & 2,5 \\
Stage 3 & 40 & 2,6 \\
ASTHMA & 50 & 3,2 \\
RESPIRATORY & 42 & 2,7 \\
HEART OPERATION & 69 & 4,5 \\
ARTERIAL HYPERTENSION & 161 & 10,4 \\
HYPERLIPIDEMIA & 81 & 5,3 \\
GASTROINTESTINAL & 80 & 5,2 \\
AIMATO $\Lambda$ OIIKA & 32 & 2,1 \\
PROSTATE HYPERTROPHY & 29 & 1,9 \\
DIABETES MELLITUS & 64 & 4,2 \\
PSYCHO-NEUROTIC & 99 & 6,4 \\
HYPOTHYROIDISM & 69 & 4,5 \\
OSTEOPOROSIS & 68 & 4,4 \\
OTHER & 43 & 2,8 \\
\hline
\end{tabular}

The smoking campaign comprised of individual supervision of smokers at four progressive periods: 2-4 weeks after the commencement of the project, 3 months, 6 and 12 and volunteers were submitted to one of the following smoking conditions: $S=$ stop smoking, $\mathrm{C}=$ continue smoking, $\mathrm{W}=$ without interview. Figure 1 shows the smoking behavior of individuals by time, thus before the end of first month the candidates reveal a great percentage of ceasing smoking $(S=83,1 \%, N=1207)$ which declines gradually and ends down to $30.6 \%$. On the other hand, a small initially portion $(\mathrm{C}=8.5 \%)$ of candidates remains bred-in-the-bone, still smoking, then increases up to $29.0 \%$ the next two periods peaking finally at $39.2 \%$ at the end of the year. A portion of $\mathrm{W}=8.4 \%$ was not interviewed in the first month and also in the $3^{\text {rd }}$ month $(9.3 \%)$ but tripled its contribution in the next two semesters $29.2 \%$ and $(30,2 \%)$.

The medical stuff of the outpatient lab suggests that the percentage of condition $\mathrm{W}$ can safely be split into two parts and increase the percentage of the other two conditions $C$ and $S$ in a ratio of 2:1 respectively, due to high experience acquired through a prolonged surveillance of smokers. As a result of this adjustment, the portion of smokers $S$ ends from the $88.7 \%$ achieved in the first month, down to $50,7 \%$ by the end of the year, whereas the portion of smokers $C$ goes from $11.3 \%$ over 49.3 at the same time (Fig. 2).

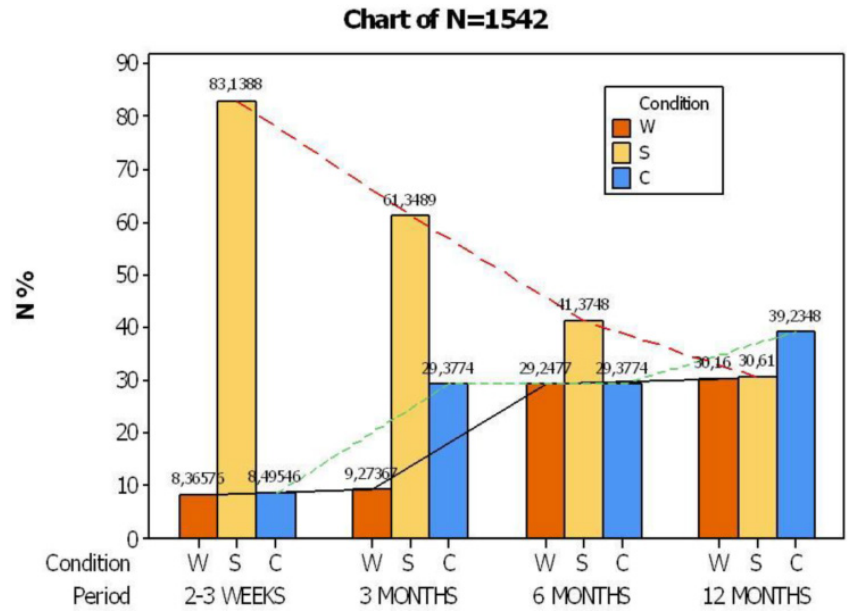

Figure I. Change of smoking supervision at four consecutive periods by time. $\mathrm{W}=$ without supervision, $\mathrm{S}=$ stop smokimg, $\mathrm{C}=$ continue to smoking.

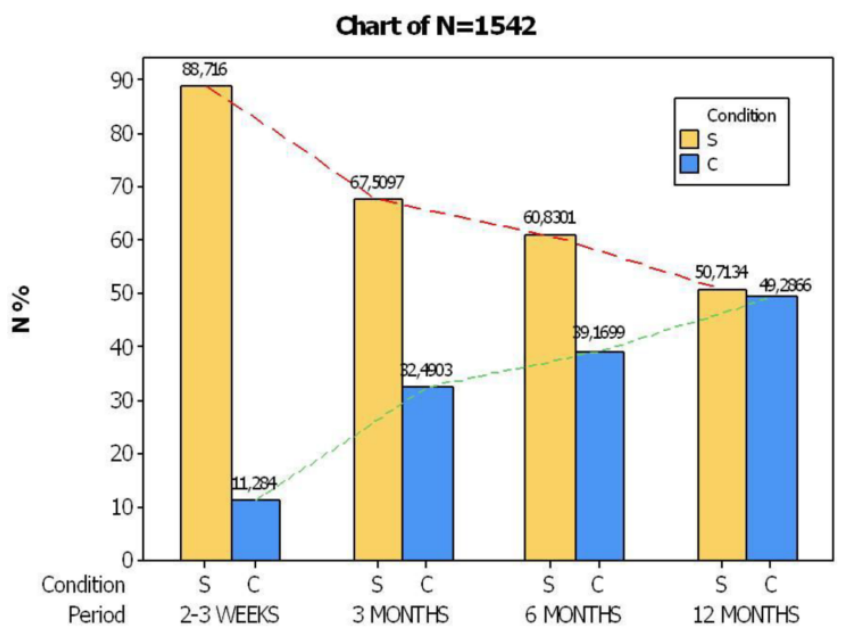

Figure 2. Change of smoking supervision at four consecutive periods by time after eliminating the effect of condition W. S= stop smokimg, C= continue to smoking.

Comparing the two trends of smoking condition at the end of year in figure 1, it comes out that $30,6 \%$ of the sample successfully quit smoking, fell shortly 9 units as compared to smokers C (39.2\%). However, taking into account the adjusted percentages in the conditions $S$ and $C$ (Fig. 2) we could infer that an encouraging perspective emerges from the smokers of condition $S$ because their portion touches $50,7 \%$ of the volunteers reflecting intimately the successful efforts of the outpatient lab.

The personalized behavior of each smoker by time was also recorded resulting in the calculation of 8 combinations of smoking condition (Fig. 3). Thus, a portion of $11,2 \%$ fulfills the antismoking campaign (SSSS, $\mathrm{N}=173$ ), a portion of $30,2 \%$ tried to conform to the antismoking requirements till the sixth month and thenceforth did not come back for interview (SSSW), and a portion of $8.4 \%$ came once for interview and that happened the last period (WWWC, N=121). One group of smokers switched from condition of ceasing 
smoking to continuation (SSWC, 20.0\%, N=308), a second group almost never stopped smoking (SCCC, $10, \%, N=154)$, a small percentage $(10,9 \%)$ wavered some time until quitting smoking (SCCS, N=168) and a portion of $8,5 \%$ demonstrated hearteningly evidence of stopping smoking by the end of the study (CCCW, $\mathrm{N}=123$ ).

Bringing back the adjusted procedure of condition $\mathrm{W}$ (people not interviewed), the aforesaid percentages are corrected as follows: conscience smokers with strong will of antismoking (SSSS) occupy 31.2\% of the total sample, those who start smoking at end of period (SSSC) reach 10,0\%, those who start smoking after semester (SSCC) reach $20 \%$, those from third month (SCCC) $10.9 \%$, whereas a percentage of $8.4 \%$ keeps smoking steadily (CCCC). On the other side, 116 smokers stop smoking at the end of study (CCCS, $8.5 \%)$ and 158 individuals continue in two minds by time (SCCS, $10.9 \%$ ).

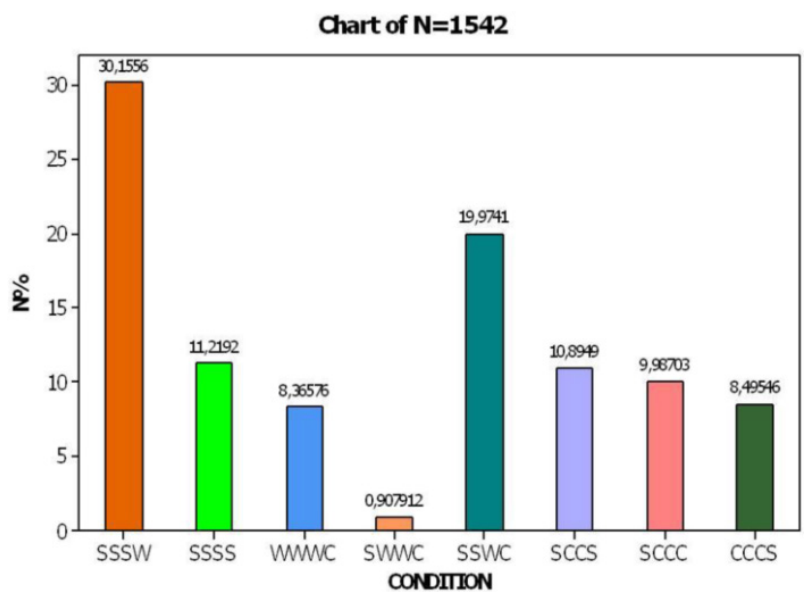

Figure 3. Percentage distribution of the smoking conditions at four periods. The succession of conditions in each combination (bar) occurs at four consecutive periods of the study.

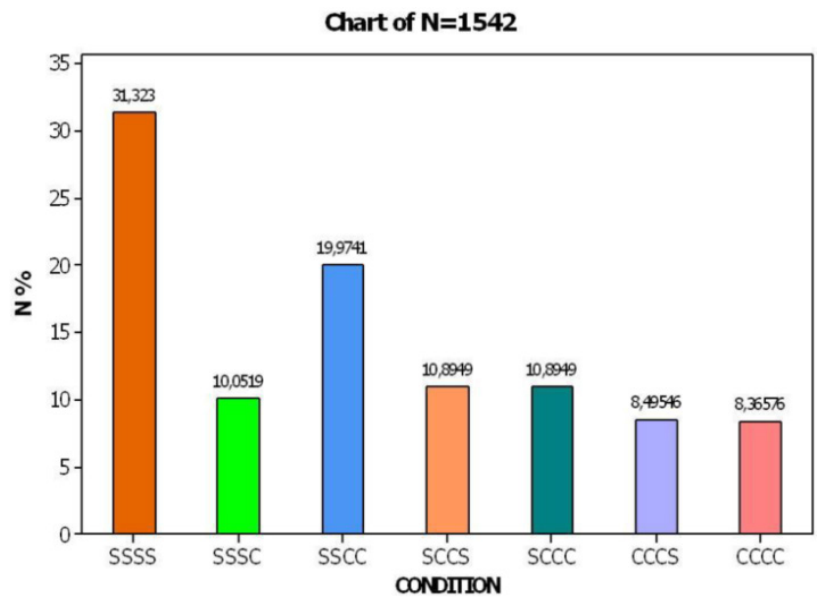

Figure 4. Percentage distribution of the smoking conditions at four periods after eliminating the effect of condition W. The succession of conditions in each combination (bar) occurs at four consecutive periods of the study.

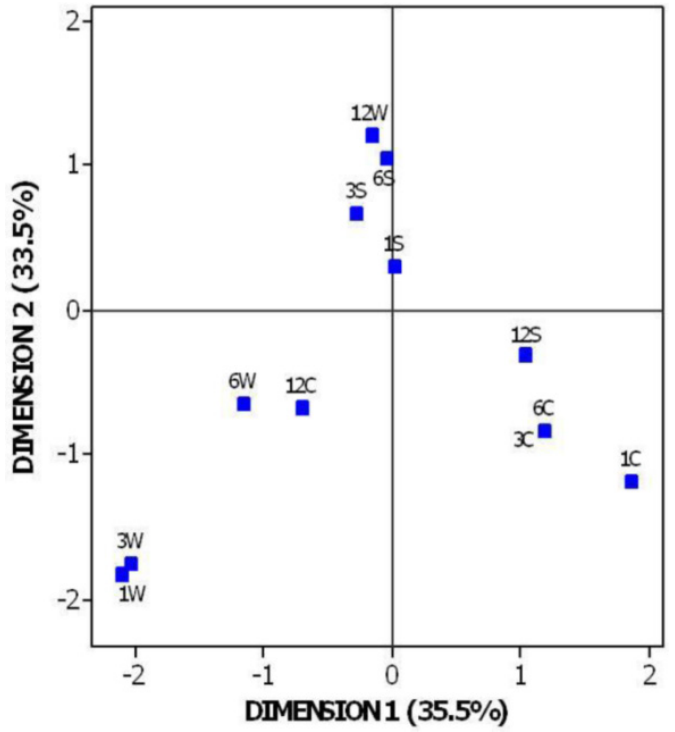

Figure 5. Distribution of the combined categories between the time of supervision and smoking condition in the space defined by the two corresponding dimensions.

Table 3 demonstrates all the possible combinations of smokers' frequency distribution at four time periods (1-4) and three conditions of smoking behavior $(\mathrm{S}, \mathrm{C}, \mathrm{W})$. The diagonal line of the table corresponds to the simple 12 combinations $(3 \times 4)$ from which the combinations $1 S$ (first month, condition S), $3 \mathrm{~S}$ and $12 \mathrm{C}$ prevail numerically in the sample (smokers 1282, 946 and 605 respectively). Minor contribution in joint pairs is observed in combination 1S-3W (14 volunteers) and maximal in 12C-6W (451). Such inner relationships between combinations are elucidated in Figure 5 resulting from the Multiple Correspondence Analysis. The first two dimensions explain $69 \%$ of the total inertia of the two entered categorical variables, time and condition, and arrange the 12 combinations in particular positions in the four quartiles of the graph so revealing three discrete groups. In this graph, points lied closely each other constitute an indication of similar behavior and distant points an inverse trend. The lower left quartile is presented by a group of smokers with no distinct will to quit smoking (condition $\mathrm{W}$ in the first three periods) because the lack of interviewing these people supports this aspect. In the lower right quartile, smokers with prolonged habit of keeping smoking until semester occupy this area and in the upper left and rather centrally volunteers who stopped smoking up to semester are distinguishable. It is noteworthy to mention that in the graph exists a reposition of the last period of supervision (twelfth month) in the three groups or, in other words, a complete lack of correspondence between conditions $12 \mathrm{~W}, 12 \mathrm{~S}$ and $12 \mathrm{C}$ with their homogeneous groups. It is easily inferred that smokers who avoided the inspection in the sixth month $(6 \mathrm{~W})$ are strongly 
connected with the condition of keeping smoking 12C due to their neighboring spatial position (451 smokers, Table 3). The fans of smoking till the third and sixth month of inspection (3C and 6C, points coincide in the graph) appear to switch on stop smoking (12S, $\mathrm{N}=598$ ) by the end of study. Finally, smokers with consecutive strong antismoking will (S) stop the interview in the twelfth month $(12 \mathrm{~W}, \mathrm{~N}=465)$. This attitude however, does not signal any negative approach, it would wiser to hypothesize that this group simply does not need any further antismoking support by the outpatient lab and thus it breaks spontaneously the inspection being already cured from the dependence on nicotine.

The impact of the social, historical and pathological factors on Fagerstrom's dependence and readiness on quitting smoking was investigated using the Analysis of Variance. Table 4 shows those factors found statistically significant, thus, men are more inclined to smoking than women $(6,8>6,4)$ and only the third attempt $(5,4)$ contributes significantly to the reduction of dependence (see also Figure 6). The presence of pathological conditions induced expectedly an increase in the smoking dependence in smokers suf- fered from respiratory problems $((7,4>6,6)$, arterial hypertension $(7.0>6.6)$, diabetes mellitus $(7.4>6.6)$ psycho-neurotic problems $(7.3>6.6)$ and a remarkable decrease from those encountered with hypothyroidism $(5.8<6.7)$.

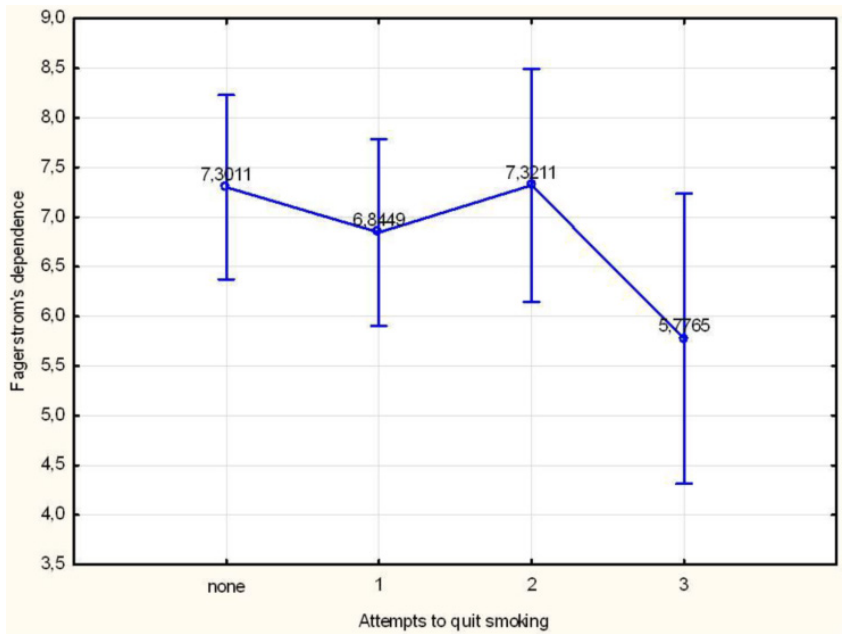

Figure 6. Mean change of Fagerstrom's dependence per trial to quit smoking. Vertical bars represent the $95 \%$ confidence intervals of means calculated from ANOVA's error mean square.

Table 3. Cross-tabulation between four periods of supervision (I,3,6 and I 2 months) and three conditions of smoking (W, S, C).

\begin{tabular}{|c|c|c|c|c|c|c|c|c|c|c|c|c|}
\hline & 1S & $1 \mathrm{C}$ & $1 W$ & $3 S$ & $3 C$ & $3 W$ & $6 S$ & $6 \mathrm{C}$ & $6 W$ & $12 S$ & $12 \mathrm{C}$ & $12 W$ \\
\hline $1 S$ & 1282 & 0 & 0 & 946 & 322 & 14 & 638 & 322 & 322 & 341 & 476 & 465 \\
\hline $1 C$ & 0 & 131 & 0 & 0 & 131 & 0 & 0 & 131 & 0 & 131 & 0 & 0 \\
\hline $1 W$ & 0 & 0 & 129 & 0 & 0 & 129 & 0 & 0 & 129 & 0 & 129 & 0 \\
\hline $3 S$ & 946 & 0 & 0 & 946 & 0 & 0 & 638 & 0 & 308 & 173 & 308 & 465 \\
\hline $3 C$ & 322 & 131 & 0 & 0 & 453 & 0 & 0 & 453 & 0 & 299 & 154 & 0 \\
\hline $3 W$ & 14 & 0 & 129 & 0 & 0 & 143 & 0 & 0 & 143 & 0 & 143 & 0 \\
\hline $6 S$ & 638 & 0 & 0 & 638 & 0 & 0 & 638 & 0 & 0 & 173 & 0 & 465 \\
\hline $6 C$ & 322 & 131 & 0 & 0 & 453 & 0 & 0 & 453 & 0 & 299 & 154 & 0 \\
\hline $6 W$ & 322 & 0 & 129 & 308 & 0 & 143 & 0 & 0 & 451 & 0 & 451 & 0 \\
\hline $12 S$ & 341 & 131 & 0 & 173 & 299 & 0 & 173 & 299 & 0 & 472 & 0 & 0 \\
\hline $12 \mathrm{C}$ & 476 & 0 & 129 & 308 & 154 & 143 & 0 & 154 & 451 & 0 & 605 & 0 \\
\hline $12 W$ & 465 & 0 & 0 & 465 & 0 & 0 & 465 & 0 & 0 & 0 & 0 & 465 \\
\hline
\end{tabular}

Table 4. Analysis of Variance of the statistically significant factors on Fagerstrom's dependence and readiness to quit smoking.

\begin{tabular}{|c|c|c|c|c|c|}
\hline Factors & SS & DF & MS & $\mathbf{F}$ & $\mathrm{p}$ \\
\hline \multicolumn{6}{|l|}{ Fagerstrom's dependence } \\
\hline AGE GROUP & 44,86 & 4 & 11,21 & 2,33 & 0,054 \\
\hline AGE GROUP* & 55,62 & 4 & 13,90 & 2,96 & 0,019 \\
\hline GENDER & 31,69 & 1 & 31,69 & 6,58 & 0,010 \\
\hline ATTEMPTS TO QUIT & 76,18 & 3 & 25,39 & 5,28 & 0,001 \\
\hline ATEMPTS TO QUIT* & 17,78 & 3 & 5,93 & 1,26 & 0,286 \\
\hline RESPIRATORY & 19,68 & 1 & 19,68 & 4,09 & 0,043 \\
\hline ARTERIAL HYPERTENSION & 19,78 & 1 & 19,78 & 4,11 & 0,043 \\
\hline DIABETES MELLITUS & 29,42 & 1 & 29,42 & 6,12 & 0,014 \\
\hline PSYCHO-NEUROTIC & 44,74 & 1 & 44,74 & 9,30 & 0,002 \\
\hline HYPOTHYROIDISM & 54,29 & 1 & 54,29 & 11,28 & 0,001 \\
\hline Error & 6957,88 & 1446 & 4,81 & & \\
\hline \multicolumn{6}{|l|}{ Readiness to quit smoking } \\
\hline Age & 193,02 & 4 & 48,25 & 6,39 & 0,000 \\
\hline Sex & 99,25 & 1 & 99,25 & 13,15 & 0,000 \\
\hline Error & 11247,17 & 1490 & 7,55 & & \\
\hline
\end{tabular}

* Significant factors only in the sub-group of endangered volunteers. 
Considering solely the sub-group of ail smokers, the pathological causations result in similar effects on smoking dependence as previously mentioned, the attempt to quit smoking does not influence the dependence, but the young age (18-25 y/o) of smokers does play an important role (Table 5). Indeed, according to figure 7 the mean dependence of youngsters differs significantly from the rest age groups since the $95 \%$ confidence intervals do not overlap bringing out a particular pattern of change: $5.0<6.7=6.9=6.8=6.9$.

Gender and age-group appear also to affect the response of readiness to stop smoking (Table 6). Men are more inclined to stop smoking comparatively to women (9.9>9.3), whereas an increasing trend of readiness by age has been established (Fig. 8). By comparing the confidence intervals, young smokers manifest a lower mean readiness on quitting smoking (8.2) adults of 26-35 and 36-45 y/o increase equally their readiness (9.3 and 9.5) and, finally, middle ages (46-65 y/o) and smokers $>65 \mathrm{y} / \mathrm{o}$ peak in even higher levels (10.0 and 10.4, respectively).

Table 5. Descriptive statistics of Fagerstrom's dependence at the various levels of the ANOVA's significant factors.

\begin{tabular}{|c|c|c|c|c|c|}
\hline & Mean & St. Error & $-95 \%$ & $+95 \%$ & $\mathbf{N}$ \\
\hline \multicolumn{6}{|l|}{ Gender } \\
\hline Men & 6,8 & 0,1 & 6,6 & 7,0 & 751 \\
\hline Women & 6,4 & 0,1 & 6,3 & 6,6 & 726 \\
\hline \multicolumn{6}{|c|}{ Age group* } \\
\hline $18-25$ & 5,0 & 0,7 & 3,6 & 6,4 & 15 \\
\hline $26-35$ & 6,7 & 0,2 & 6,2 & 7,2 & 75 \\
\hline $36-45$ & 6,9 & 0,2 & 6,6 & 7,2 & 185 \\
\hline $46-65$ & 6,8 & 0,1 & 6,5 & 7,0 & 324 \\
\hline$>65$ & 6,9 & 0,3 & 6,2 & 7,5 & 31 \\
\hline \multicolumn{6}{|c|}{ Attempts to quit } \\
\hline none & 6,7 & 0,1 & 6,6 & 6,8 & 1118 \\
\hline 1 & 6,3 & 0,1 & 6,1 & 6,6 & 314 \\
\hline 2 & 6,9 & 0,4 & 6,0 & 7,8 & 31 \\
\hline 3 & 5,4 & 0,6 & 4,0 & 6,7 & 14 \\
\hline \multicolumn{6}{|c|}{ Respiratory } \\
\hline 0 & 6,6 & 0,1 & 6,5 & 6,7 & 1435 \\
\hline 1 & 7,4 & 0,3 & 6,8 & 8,0 & 42 \\
\hline \multicolumn{6}{|c|}{ Arterial hypertension } \\
\hline 0 & 6,6 & 0,1 & 6,5 & 6,7 & 1325 \\
\hline 1 & 7,0 & 0,2 & 6,7 & 7,4 & 152 \\
\hline \multicolumn{6}{|c|}{ Diabetes mellitus } \\
\hline 0 & 6,6 & 0,1 & 6,5 & 6,7 & 1416 \\
\hline 1 & 7,4 & 0,3 & 6,8 & 7,9 & 61 \\
\hline \multicolumn{6}{|c|}{ Psycho-neurotic } \\
\hline 0 & 6,6 & 0,1 & 6,5 & 6,7 & 1384 \\
\hline 1 & 7,3 & 0,2 & 6,9 & 7,8 & 93 \\
\hline \multicolumn{6}{|c|}{ Hypothyroidism } \\
\hline 0 & 6,7 & 0,1 & 6,5 & 6,8 & 1408 \\
\hline 1 & 5,8 & 0,3 & 5,2 & 6,4 & 69 \\
\hline
\end{tabular}

Table 6. Descriptive statistics of readiness to quit at the various levels of the ANOVA's significant factors.

\begin{tabular}{llllll}
\hline & Mean & St. Error & $\mathbf{- 9 5 \%}$ & $\mathbf{+ 9 5 \%}$ & $\mathbf{N}$ \\
\hline $\begin{array}{l}\text { Gender } \\
\text { Men }\end{array}$ & 9,9 & 0,1 & & & \\
Women & 9,3 & 0,1 & 9,7 & 10,1 & 779 \\
Age group & & 9,1 & 9,5 & 742 \\
18-25 & 8,2 & 0,4 & & & \\
$26-35$ & 9,3 & 0,2 & 7,4 & 9,0 & 55 \\
$36-45$ & 9,5 & 0,1 & 9,0 & 9,6 & 279 \\
$46-65$ & 10,0 & 0,1 & 9,2 & 9,7 & 500 \\
$>65$ & 10,4 & 0,4 & 9,7 & 10,2 & 629 \\
\hline
\end{tabular}

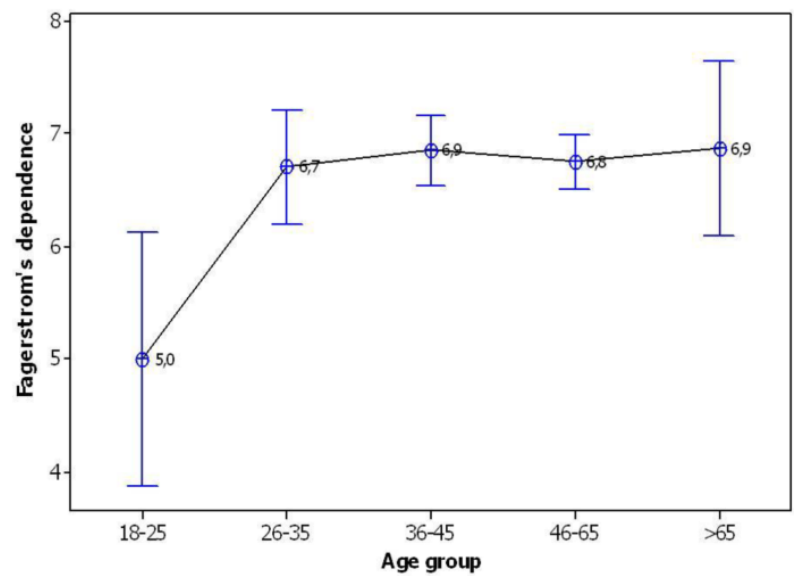

Figure 7. Mean change of Fagerstrom's dependence per age group. Vertical bars represent the $95 \%$ confidence intervals of means calculated from ANOVA's error mean square.

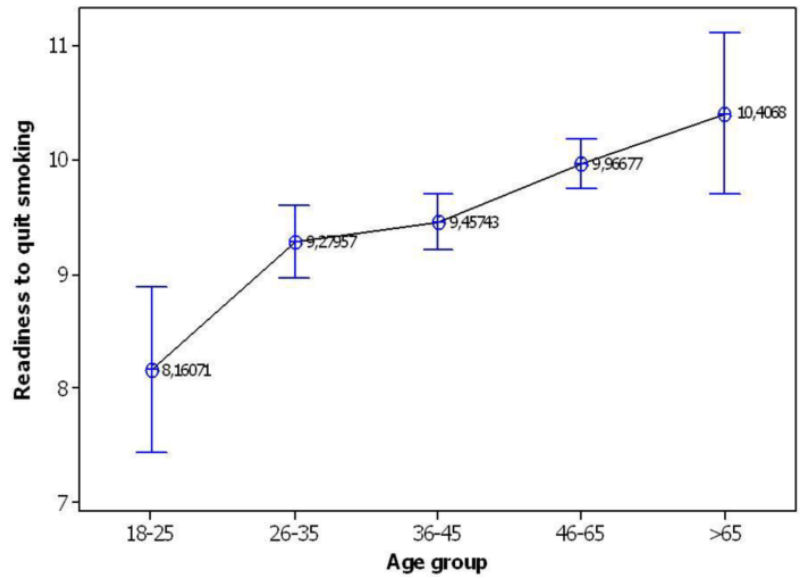

Figure 8. Mean change of readiness to quit smoking per age group. Vertical bars represent the $95 \%$ confidence intervals of means calculated from ANOVA's error mean square. 
Possible implications among categories of the variables under study targeting exclusively to Fagerstrom's dependence were explored by the CHAID's regression tree (Fig. 9). People suffered from hypothyroidism are completely distinguished from the rest sample signifying the importance of this disease on smoking dependence because it definitely reduces the smoking intensity (5.8, 69 individuals). Of second importance, smokers with psycho-neurotic symptoms and in the absence of hypothyroidism, meaning that 5 smokers suffering from hypothyroidism are excluded from further analysis, increase their dependence (7.4, $\mathrm{N}=87$ ). Women without carrying the previous symptoms but with arterial hypertension also increase the Fagertstrom's dependence (7.1) as compared to healthy ones (6.3). Men free from the $p$ revious symptoms but having gastrointestinal problems revalued the intensity of dependence against the healthy ones $(7.6>6.7)$. The latter men are related with greater smoking dependence when they learn about the activities of outpatient lab through the surrounding environment (6.8) instead from mass media (6.3). In the case of the sub-group of endangered people, the general view partly changes: the most important pathological variables (hypothyroidism and psycho-neurotic) still and similarly govern the smoking dependence (Fig. 10). In the absence of the above symptoms, hyperlipidemic smokers do not seem to increase the level of dependence (6.2) in contract with the healthy part which shows higher mean value (6.9) which further increases in case of men (7.1) but lowers in case of women (6.6). These women, from previous diseases, manifest higher dependence when suffer from arterial hypertension (7.3) in contract to wealthy part (6.3). In conclusion, the basic differences between the whole sample and the fail subgroup are focused in the gastrointestinal symptoms and the type of message propagation that affect the whole sample of 1452 individuals and the hyperlipidemia that is important in the sample of endangered people (630).

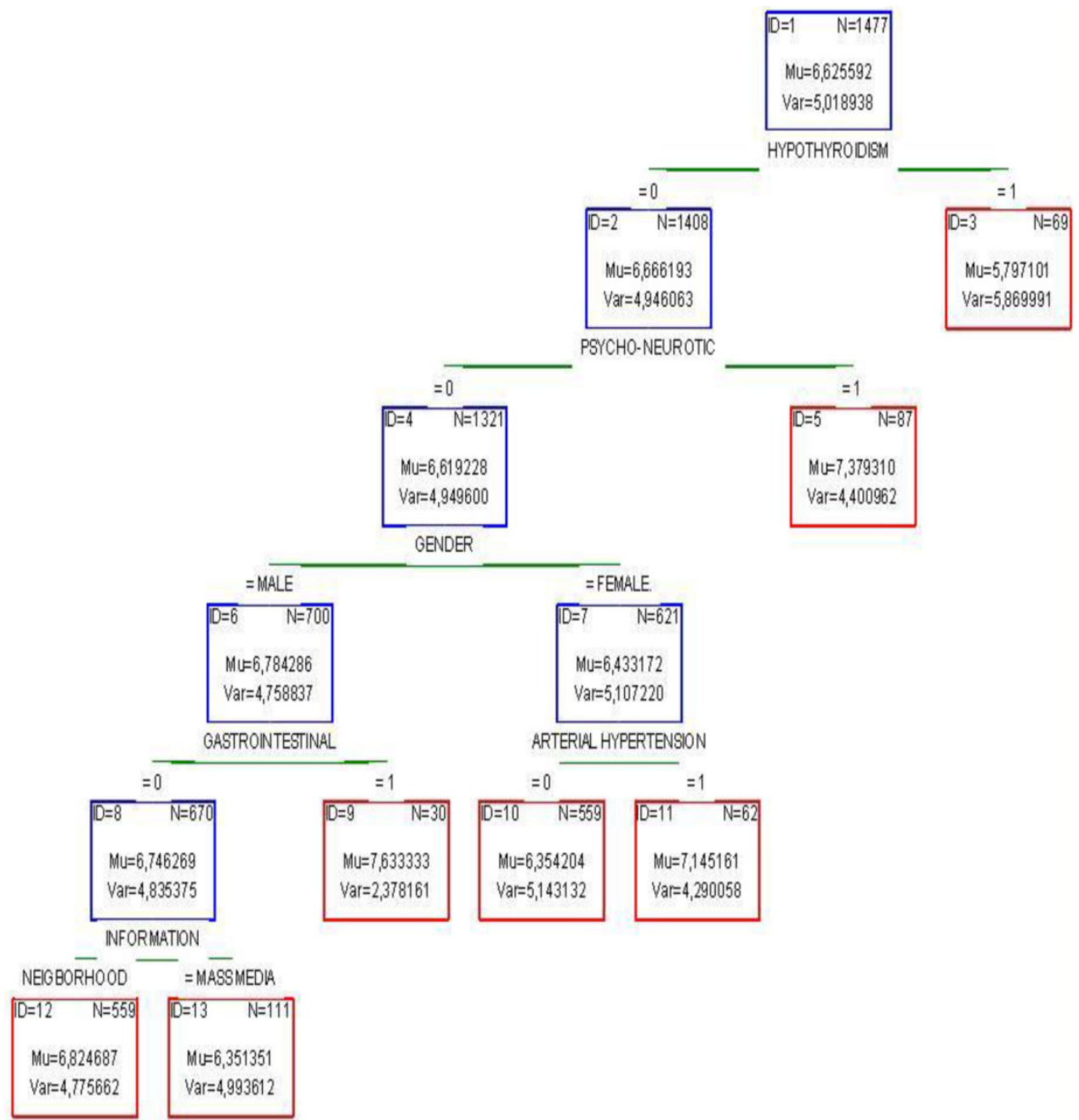

Figure 9. Dendrogram produced by CHAID's regression tree depicting the dependent Fagerstrom's variable and six independent variables. Mu=mean value, $\mathrm{Var}=$ variance. Risk estimate (variance): 4.87 , St. error: 0.17 . 10 -fold cross validation: 5.10 , St. error: 0.18 


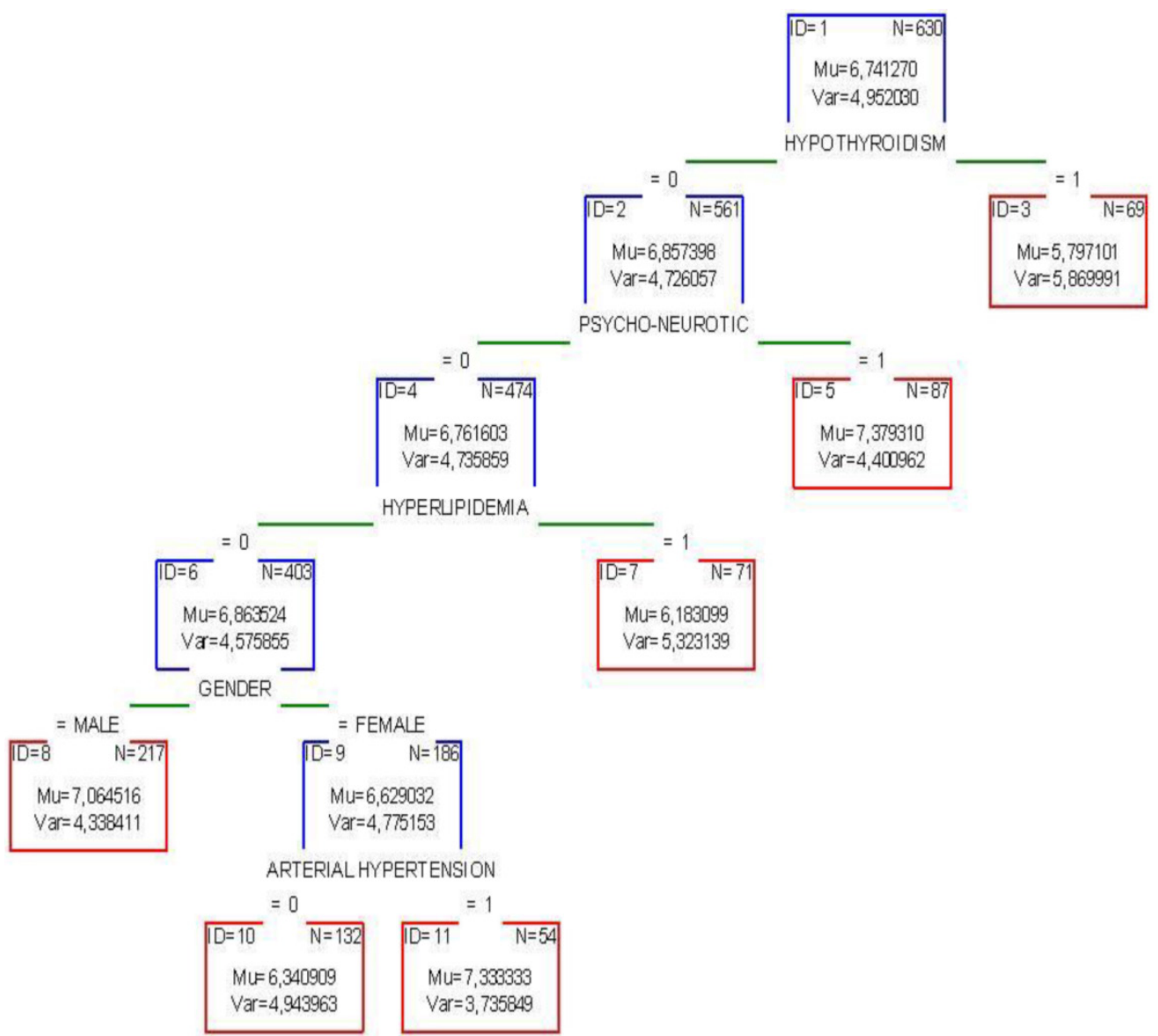

Figure 10. Dendrogram produced by CHAID's regression tree depicting the dependent Fagerstrom's dependence and five independent variables. $M u=$ mean value, $V a r=$ variance. Risk estimate (variance): 4.66 , St. error: 0.26 . I0-fold cross validation: 4.99 St. error: 0.27

The Fagerstrom's dependence was regressesed as ordinal dependent variable (three classes- low, medium, strong)) against all the variables of the study considered as independent. This technique facilitates the comparison and interpretation of the results via the adoption of the term odds ratio and is extremely popular when plenty of categorical variables are present. The strong class of dependence as compared to the low class, produces 33\% higher effect (or the result is 1.33 times greater) on volunteers who have been informed about the activities of the outpatient lab from the surrounding environment in regards to those who took the message by mass media (Table 7). Smokers who tried to stop smoking three times demonstrate $84 \%$ lower dependence (1-0.14) as compared to those who never tried so, or in other words, they exhibit 7.1 times higher probability to quit smoking (1/0.14). A similar attitude but of smaller scale $(27 \%$, or 1.4 times) is obvious for those quitting smoking once. Smokers suffering from COPD third stage are expected to show 2.8 times higher probabil- ity of nicotine dependence than the healthy ones. Similarly, smokers with psycho-neurotic symptoms are about to increase their dependence 1.8 times more than others. On the contrary, individuals with hypothyroidism are expected to lessen the smoking dependence down to $50 \%$ or 1.9 times against the other smokers. The last two pathologic conditions exert exactly the same effect on the sub-group with the endangered people and moreover age exerts an increasing trend of dependence. Specifically, age groups greater than $25 \mathrm{y} /$ o manifest a 4 times greater probability to be addicted as compared to younger smokers (18-25).

The treatment administered to smokers throughout the period of inspection seems to also have a significant effect on dependence. In fact, varelicline causes a $50 \%$ reduction in smoking dependence in regards to nicotine substitutes (odds ratio: $0.48(0.31-0,74), p=0.001)$ so displaying a substantial preponderance on the choice to fight smoking dependence. 
Table 7. Statistically significant effects produced by regressing the Fagerstrom's three-class dependence against the variables of the study. Italic values denote significant effect at 0.05 probability level of reference. The variables were selected after applying the stepwise technique of backward removal. Maximum likelihood $=-1372,832$, Equality of slopes: $G=48,692, D F=9, p=0,000$, Goodness of fit tests [Method/X2/DF/P: Pearson/97,28/93/0,360; Deviance/91,56/93/0,523]

\begin{tabular}{|c|c|c|c|c|c|c|c|c|}
\hline Variable & Reference category & Coefficient & St. Error & Z value & p & Odds ratio & $-95 \%$ & $95 \%$ \\
\hline \multicolumn{9}{|l|}{ Information } \\
\hline Surrounding environment & Mass media & 0,287 & 0,132 & 2,17 & 0,030 & 1,33 & 1,03 & 1,72 \\
\hline Attempts to quit & 0 & & & & & & & \\
\hline 1 & & $-0,312$ & 0,124 & $-2,51$ & 0,012 & 0,73 & 0,57 & 0,93 \\
\hline 2 & & 0,416 & 0,359 & 1,16 & 0,247 & 1,52 & 0,75 & 3,07 \\
\hline 3 & & $-1,968$ & 0,525 & $-3,75$ & 0,010 & 0,14 & 0,05 & 0,39 \\
\hline COPD & 0 & & & & & & & \\
\hline 1 & & 0,188 & 0,181 & 1,04 & 0,298 & 1,21 & 0,85 & 1,72 \\
\hline 2 & & 0,54 & 0,325 & 1,66 & 0,096 & 1,72 & 0,91 & 3,24 \\
\hline 3 & & 1,023 & 0,344 & 2,97 & 0,003 & 2,78 & 1,42 & 5,46 \\
\hline Psycho-neurotic & 0 & & & & & & & \\
\hline 1 & & 0,574 & 0,211 & 2,72 & 0,007 & 1,78 & 1,17 & 2,69 \\
\hline Hypothyroidism & 0 & & & & & & & \\
\hline 1 & & $-0,635$ & 0,243 & $-2,61$ & 0,009 & 0,53 & 0,33 & 0,85 \\
\hline Age group & $18-25$ & & & & & & & \\
\hline $26-35$ & & 1,465 & 0,555 & 2,64 & 0,008 & 4,33 & 1,46 & 12,83 \\
\hline $36-45$ & & 1,52 & 0,528 & 2,88 & 0,004 & 4,57 & 1,63 & 12,86 \\
\hline $46-65$ & & 1,431 & 0,519 & 2,76 & 0,006 & 4,18 & 1,51 & 11,56 \\
\hline$>65$ & & 1,276 & 0,615 & 2,08 & 0,038 & 3,58 & 1,07 & 11,95 \\
\hline
\end{tabular}

Table 8. Cross-tabulation of Fagerstrom's dependence in the various levels of the significant variables after applying the logistic regression.

\begin{tabular}{|c|c|c|c|c|c|}
\hline Variable & & $\mathbf{N}$ & Fager-1 & Fager- 2 & Fager- 3 \\
\hline Total sample & Category & 1477 & 143 & 749 & 585 \\
\hline INFORMATION & Surrounding environment & 1216 & 109 & 613 & 494 \\
\hline INFORMATION & Mass media & 261 & 34 & 136 & 91 \\
\hline Attempts to quit & none & 1118 & 91 & 574 & 453 \\
\hline Attempts to quit & 1 & 314 & 42 & 159 & 113 \\
\hline Attempts to quit & 2 & 31 & 4 & 10 & 17 \\
\hline Attempts to quit & 3 & 14 & 6 & 6 & 2 \\
\hline COPD & 0 & 1275 & 128 & 659 & 488 \\
\hline COPD & 1 & 127 & 10 & 62 & 55 \\
\hline COPD & 2 & 38 & 3 & 16 & 19 \\
\hline COPD & 3 & 37 & 2 & 12 & 23 \\
\hline PSYCHO-NEUROTIC & 0 & 1384 & 138 & 711 & 535 \\
\hline PSYCHO-NEUROTIC & 1 & 93 & 5 & 38 & 50 \\
\hline HYPOTHYROIDISM & 0 & 1408 & 131 & 713 & 564 \\
\hline HYPOTHYROIDISM & 1 & 69 & 12 & 36 & 21 \\
\hline Sub-group & Category & 633 & 60 & 312 & 261 \\
\hline Age group & $18-25$ & 15 & 5 & 7 & 3 \\
\hline Age group & $26-35$ & 75 & 4 & 42 & 29 \\
\hline Age group & $36-45$ & 186 & 13 & 93 & 80 \\
\hline Age group & $46-65$ & 326 & 36 & 152 & 138 \\
\hline Age group & $>65$ & 31 & 2 & 18 & 11 \\
\hline
\end{tabular}

\section{Discussion}

Smoking has been associated with several adverse effects in human health. The categories that are most vulnerable to smoking initiation are the adolescents and young adults $[35,36]$. Factors affecting the smoking habit are; age, movie smoking, economic status, migration history, ethnicity, mother smoking, sibling smoking, peer smoking, sensation seeking and school performance [36]. Several genes have been also implicated in smoking initiation and smoking habit [37]. Therefore it has been proposed that seeking genes that regulate smoking is useful, since they could be future targets as therapy [37]. In the study by Harari O. et al. [38] cholinergic and sensory pathways were associated with quantity of smoking. Smoking has been associated with periodontal disease which could lead to tooth loss [39]. Vasoconstriction of the placenta vessels has been also observed in women smokers which also lead to fetus malnutrition and low weight upon birth [40]. The group of young pregnant women has been identified as one of the most difficult group to handle for smoking cessation, since there are clusters of factors that need to be handled simulta- 
neously [41]. Sleep disturbances have been also observed to be higher in smokers than non-smokers and health adverse effects were also more common [42]. This observation comes in accordance with the high rate of coronary artery disease observed in smokers than non-smokers [43]. Sleep disturbances have been also found to be increased in women with smoking habit [44]. Moreover; smoking has been observed to be a risk factor for chronic musculoskeletal complaints for people until the age of 50 . The complaints were associated with smoking habit and there was no increase in severity of the symptoms after the age of 50 [45]. Smoking has been identified as a risk factor for pregnant women and infants [46]. Smoking has been also associated with implant failure [47]. Osteoporosis has been observed to be increased in patients with smoking habit [48]. There has been an effort to identify whether different scales for smoking habit evaluation should be designed and incorporated for different populations. Indeed, this effort identified also the need for different sensation seeking scales for different populations with different background [34]. Health-related quality of life in the general population has been found to be associated with quantity of smoking and gender [30]. In the study by Kalucka S. et al. [49] it was observed that cigarette smokers have chronic diseases (respiratory and coronary) earlier than in the non-smokers group. Worse physical and phychological health of smokers reduced social activity and decreased quality of life. Metabolic syndrome has been associated with high risk of metabolic syndrome manifestation, however; the underlying mechanisms are not clear [50]. Depression and the socioeconomic status have been found to be closely associated in adulthood [51]. Furthermore, parental smoking during pregnancy and total and abdominal fat distribution in school-age children have been found to be closely associated in a dose dependent manner [52]. In another study by Sharafutdinova LR. Et al. [53] a strong association was observed between development and progression of multiple sclerosis. In the study by Stephens BF. Et al. [54] a strong association was found between nutritional deficiencies, smoking, and systemic disease on orthopaedic outcomes. Smoking habit has been also associated with the increase in atypical proteins in lung cancer patients which are responsible for immunomodualtion [55]. In smoking patients with pancreatitis, again urea, uric acid and creatinine were found to be increased [56]. Pulmonary fibrosis manifestation was observed increased in smoking patients, especially among men and those with occupational exposure [57]. It was observed in the study by Vlassopoulos A. et al. [58] that smoking, glycated haemoglobin levels and 'pre-diabetes`categorization were strongly associated in a dose dependent manner. Smoking cessation with more intense methods have failed to present better results in diabetic patients [59]. Smoking is well known to be associated with lung cancer and COPD $[60,61]$. However; in the study by Braganza M. et al. [62] smoking and alcohol were not associated with glioma cancer. In another study by Judy Peres [63] data were presented for 76.000 women were there was a strong association of lung cancer and smoking, but however; no clear link was observed for lung cancer and second hand smoke. Additionally, different types of smoking tobacco have been found to be associated with different adverse effects on pulmonary functions. In specific narghile smokers have been found to have their pulmonary functions less decreased when compared to the same smoking habit as those smoking other types of tobacco [64]. Several pharmacological and non-pharmacological methods are being used for smoking cessation [31, 65]. Barriers for smoking cessation are considered; addiction, fear of weight gain, and depression. Pharmacological interventions are considered; nicotine injection, nicotine polacrilex gums, nicotine lozenge, nicotine trans-dermal patch, nicotine aerosol, gel-like droplet of nicotine, bupropion, nortriptyline, clonidine, anxiolytics, and varenicline. Furthermore; there is also nicotine blockage therapy with mecamylamine and naltrexone. A new drug for smoking cessation is NicVax which stimulates the immune system [65]. Nicotine withdrawal has been associated with mental illness and patients with mental illness have been observed to be less successful in smoking cessation [66]. A rare case of smoking cessation has been also reported by using gamma knife in a patient with vestibular schwannoma [67]. Moreover; varenicline administration for smoking cessation has been found to additionally decrease oxidative stress and restore endothelial function which is so important in copd patients and inhibits emphysema progression [68]. Opiod antagonists have not been found to increase the efficiency of smoking cessation [69]. In any case long term smokers and non-smokers, who survive into old age appear to be at increased risk for non-life-threatening conditions that can diminish quality of life and increase demands for services [70]. In another study by He et al. [43] it was observed that when smoking cessation was accomplished around 50 years of age then the risk of death was substantially reduced. In our study, men are more inclined to stop smoking comparatively to women $(9.9>9.3)$, whereas an increasing trend of readiness by age has been established. By comparing the confidence intervals, young smokers manifest a lower mean readiness on quitting smoking (8.2) adults of 26-35 and 36-45 y/o increase equally their readiness (9.3 and 9.5) and, fi- 
nally, middle ages (46-65 y/o) and smokers $>65 \mathrm{y} / \mathrm{o}$ peak in even higher levels (10.0 and 10.4, respectively). Smokers suffering from COPD third stage are expected to show 2.8 times higher probability of nicotine dependence than the healthy ones. Similarly, smokers with psycho-neurotic symptoms are about to increase their dependence 1.8 times more than others. On the contrary, individuals with hypothyroidism are expected to lessen the smoking dependence down to $50 \%$ or 1.9 times against the other smokers. In conclusion, the basic differences between the whole sample and the fail subgroup are focused in the gastrointestinal symptoms and the type of message propagation that affect the whole sample of 1452 individuals and the hyperlipidemia that is important in the sample of endangered people (630). Varelicline caused a 50\% reduction in smoking dependence in regards to nicotine substitutes (odds ratio: $0.48(0.31-0,74), \mathrm{p}=0.001$ ) so displaying a substantial preponderance on the choice to fight smoking dependence.

\section{Competing Interests}

None to declare.

\section{References}

1. Siegel R, Naishadham D, Jemal A. Cancer statistics, 2012. CA Cancer J Clin. 2012; 62: 10-29. doi:10.3322/caac.20138.

2. Mirsadraee S, Oswal D, Alizadeh Y, Caulo A, van Beek E, Jr. The 7th lung cancer TNM classification and staging system: Review of the changes and implications. World J Radiol. 2012; 4: 128-34. doi:10.4329/wjr.v4.i4.128.

3. Zarogoulidis P, Chatzaki E, Hohenforst-Schmidt W, Goldberg EP, Galaktidou G, Kontakiotis T, et al. Management of malignant pleural effusion by suicide gene therapy in advanced stage lung cancer: a case series and literature review. Cancer Gene Ther. 2012; 19: 593-600. doi:10.1038/cgt.2012.36cgt201236 [pii].

4. Porpodis K, Karanikas M, Zarogoulidis P, Kontakiotis T, Mitrakas A, Esebidis A, et al. A case of typical pulmonary carcinoid tumor treated with bronchoscopic therapy followed by lobectomy. J Multidiscip Healthc. 2012; 5: 47-51. doi:10.2147/JMDH.S29709jmdh-5-047 [pii]

5. Wang YT, Huang G. Is FDG PET/CT cost-effective for pre-operation staging of potentially operative non-small cell lung cancer? - From Chinese healthcare system perspective. Eur J Radiol. 2012; 81: e903-9. doi:10.1016/j.ejrad.2012.05.006S0720-048X(12)00233-1 [pii].

6. Yarmus L, Akulian J, Gilbert C, Feller-Kopman D, Lee HJ, Zarogoulidis P, et al. Optimizing endobronchial ultrasound for molecular analysis. How many passes are needed? Ann Am Thorac Soc. 2013; 10: 636-43. doi:10.1513/AnnalsATS.201305-130OC.

7. Hohenforst-Schmidt W, Zarogoulidis P, Vogl T, Turner JF, Browning R, Linsmeier B, et al. Cone Beam Computertomography (CBCT) in Interventional Chest Medicine - High Feasibility for Endobronchial Realtime Navigation. J Cancer. 2014; 5: 231-41. doi:10.7150/jca.8834jcav05p0231 [pii].

8. Hohenforst-Schmidt W, Banckwitz R, Zarogoulidis P, Vogl T, Darwiche K, Goldberg E, et al. Radiation Exposure of Patients by Cone Beam CT during Endobronchial Navigation - A Phantom Study. J Cancer. 2014; 5: 192-202. doi:10.7150/jca.8395jcav05p0192 [pii].

9. Nishino M, Cardarella S, Jackman DM, Ramaiya NH, Rabin MS, Hatabu H, et al. RECIST 1.1 in NSCLC patients with EGFR mutations treated with EGFR tyrosine kinase inhibitors: comparison with RECIST 1.0. AJR Am J Roentgenol. 2013; 201: W64-71. doi:10.2214/AJR.12.9668.

10. Zaric B, Stojsic V, Sarcev T, Stojanovic G, Carapic V, Perin B, et al. Advanced bronchoscopic techniques in diagnosis and staging of lung cancer. J Thorac Dis. 2013; 5: S359-S70. doi:10.3978/j.issn.2072-1439.2013.05.15jtd-05-S4-S359 [pii].

11. Baltayiannis $\mathrm{N}$, Chandrinos $\mathrm{M}$, Anagnostopoulos D, Zarogoulidis $\mathrm{P}$, Tsakiridis K, Mpakas A, et al. Lung cancer surgery: an up to date. J Thorac Dis. 2013; 5: S425-S39. doi:10.3978/j.issn.2072-1439.2013.09.17jtd-05-S4-S425 [pii].

12. Kallianos A, Rapti A, Zarogoulidis P, Tsakiridis K, Mpakas A, Katsikogiannis N, et al. Therapeutic procedure in small cell lung cancer. J Thorac Dis. 2013; 5: S420-S4. doi:10.3978/j.issn.2072-1439.2013.09.16jtd-05-S4-S420 [pii]

13. Boukovinas I, Tsakiridis K, Zarogoulidis P, Machairiotis N, Katsikogiannis N, Kougioumtzi I, et al. Neo-adjuvant chemotherapy in early stage non-small cell lung cancer. J Thorac Dis. 2013; 5: S446-S8. doi:10.3978/j.issn.2072-1439.2013.07.36jtd-05-S4-S446 [pii].

14. Zarogoulidis K, Zarogoulidis P, Darwiche K, Boutsikou E, Machairiotis N, Tsakiridis K, et al. Treatment of non-small cell lung cancer (NSCLC). J Thorac Dis. 2013; 5: S389-S96. doi:10.3978/j.issn.2072-1439.2013.07.10jtd-05-S4-S389 [pii].

15. Zaric B, Stojsic V, Tepavac A, Sarcev T, Zarogoulidis P, Darwiche K, et al. Adjuvant chemotherapy and radiotherapy in the treatment of non-small cell lung cancer (NSCLC). J Thorac Dis. 2013; 5: S371-S7. doi:10.3978/j.issn.2072-1439.2013.05.16jtd-05-S4-S371 [pii].

16. Zarogoulidis K, Boutsikou E, Zarogoulidis P, Darwiche K, Freitag L, Porpodis $\mathrm{K}$, et al. The role of second-line chemotherapy in small cell lung cancer: a retrospective analysis. Onco Targets Ther. 2013; 6: 1493-500. doi:10.2147/OTT.S52330ott-6-1493 [pii].

17. Domvri K, Zarogoulidis P, Darwiche K, Browning RF, Li Q, Turner JF, et al. Molecular Targeted Drugs and Biomarkers in NSCLC, the Evolving Role of Individualized Therapy. J Cancer. 2013; 4: 736-54. doi:10.7150/jca.7734jcav04p0736 [pii]

18. Zarogoulidis P, Mavroudi M, Porpodis K, Domvri K, Sakkas A, Machairiotis $\mathrm{N}$, et al. Pegylated liposomal doxorubicin in malignant pleural mesothelioma: a possible guardian for long-term survival. Onco Targets Ther. 2012; 5: 231-6. doi:10.2147/OTT.S36915ott-5-231 [pii].

19. Zarogoulidis P, Kerenidi T, Huang H, Kontakiotis T, Tremma O, Porpodis K, et al. Six minute walking test and carbon monoxide diffusing capacity for non-small cell lung cancer: easy performed tests in every day practice. J Thorac Dis. 2012; 4: 569-76. doi:10.3978/j.issn.2072-1439.2012.08.18jtd-04-06-569 [pii].

20. Travis LB, Fossa SD, Sesso HD, Frisina RD, Herrmann DN, Beard CJ, et al. Chemotherapy-Induced Peripheral Neurotoxicity and Ototoxicity: New Paradigms for Translational Genomics. J Natl Cancer Inst. 2014. doi:dju044 [pii]10.1093/jnci/dju044.

21. Liu HB, Wu Y, Lv TF, Yao YW, Xiao YY, Yuan DM, et al Skin rash could predict the response to EGFR tyrosine kinase inhibitor and the prognosis for patients with non-small cell lung cancer: a systematic review and meta-analysis. PLoS One. 2013; 8: 555128. doi:10.1371/journal.pone.0055128PONE-D-12-35276 [pii]

22. Elbehairy AF, Webb KA, Alberto Neder J, O'Donnell DE. Should Mild COPD Be Treated? Evidence for Early Pharmacological Intervention. Drugs. 2013; 73: 1991-2001. doi:10.1007/s40265-013-0145-9.

23. Chrystyn H, Small M, Milligan G, Higgins V, Gil EG, Estruch J. Impact of patients' satisfaction with their inhalers on treatment compliance and health status in COPD. Respir Med. 2013. doi:S0954-6111(13)00386-7 [pii]10.1016/j.rmed.2013.09.021.

24. Siafakas NM, Antoniou KM, Tzortzaki EG. Role of angiogenesis and vascular remodeling in chronic obstructive pulmonary disease. Int J Chron Obstruct Pulmon Dis. 2007; 2: 453-62.

25. Shapiro SD. Proteinases in chronic obstructive pulmonary disease. Biochem Soc Trans. 2002; 30: 98-102. doi:10.1042/

26. MacNee W. Pulmonary and systemic oxidant/antioxidant imbalance in chronic obstructive pulmonary disease. Proc Am Thorac Soc. 2005; 2: 50-60. doi:2/1/50 [pii]10.1513/pats.200411-056SF.

27. Curtis JL, Freeman CM, Hogg JC. The immunopathogenesis of chronic obstructive pulmonary disease: insights from recent research. Proc Am Thorac Soc. 2007; 4: 512-21. doi:4/7/512 [pii]10.1513/pats.200701-002FM.

28. Willemse BW, ten Hacken NH, Rutgers B, Lesman-Leegte IG, Postma DS, Timens W. Effect of 1-year smoking cessation on airway inflammation in COPD and asymptomatic smokers. Eur Respir J. 2005; 26: 835-45. doi:26/5/835 [pii]10.1183/09031936.05.00108904.

29. Zarogoulidis P, Papanas N, Kioumis I, Chatzaki E, Maltezos E, Zarogoulidis K. Macrolides: from in vitro anti-inflammatory and immunomodulatory properties to clinical practice in respiratory diseases. Eur J Clin Pharmacol. 2012; 68: 479-503. doi:10.1007/s00228-011-1161-x.

30. Coste J, Quinquis L, D'Almeida S, Audureau E. Smoking and health-related quality of life in the general population. Independent relationships and large differences according to patterns and quantity of smoking and to gender. PLOS One. 2014; 9: e91562. doi:10.1371/journal.pone.0091562PONE-D-13-45725 [pii].

31. Ozturk C, Kararli Bingul A. Implementation of pharmacological and various nonpharmacological interventions for a smoking cessation program in the environment of an outpatient clinic. Chest. 2014; 145: 431E. doi:10.1378/chest.19230021841508 [pii].

32. Wilkinson AV, Gabriel KP, Wang J, Bondy ML, Dong Q, Wu X, et al. Sensation-seeking genes and physical activity in youth. Genes Brain Behav. 2013; 12: 181-8. doi:10.1111/gbb.12006.

33. Strasser AA, Ashare RL, Kaufman M, Tang KZ, Mesaros AC, Blair IA. The effect of menthol on cigarette smoking behaviors, biomarkers and subjective responses. Cancer Epidemiol Biomarkers Prev. 2013; 22: 382-9. doi:10.1158/1055-9965.EPI-12-10971055-9965.EPI-12-1097 [pii].

34. Chen X, Li F, Nydegger L, Gong J, Ren Y, Dinaj-Koci V, et al. Brief Sensation Seeking Scale for Chinese - Cultural Adaptation and Psychometric Assessment. Pers Individ Dif. 2013; 54: 604-9. doi:10.1016/j.paid.2012.11.007.

35. Balevich EC, Wein ND, Flory JD. Cigarette smoking and measures of impulsivity in a college sample. Subst Abus. 2013; 34: 256-62. doi:10.1080/08897077.2012.763082.

36. Morgenstern M, Sargent JD, Engels RC, Florek E, Hanewinkel R. Smoking in European adolescents: relation between media influences, family affluence, 
and migration background. Addict Behav. 2013; 38: 2589-95. doi:10.1016/j.addbeh.2013.06.008S0306-4603(13)00168-8 [pii].

37. Doran N, Schweizer CA, Myers MG, Greenwood TA. A prospective study of the effects of the DRD2/ANKK1 TaqIA polymorphism and impulsivity on smoking initiation. Subst Use Misuse. 2013; 48: 106-16. doi:10.3109/10826084.2012.733791.

38. Harari O, Wang JC, Bucholz K, Edenberg HJ, Heath A, Martin NG, et al. Pathway analysis of smoking quantity in multiple GWAS identifies cholinergic and sensory pathways. PLoS One. 2012; 7: e50913. doi:10.1371/journal.pone.0050913PONE-D-12-16320 [pii].

39. Sherwin GB, Nguyen D, Friedman Y, Wolff MS. The relationship between smoking and periodontal disease. Review of literature and case report. N Y State Dent J. 2013; 79: 52-7.

40. Machaalani R, Ghazavi E, Hinton T, Waters KA, Hennessy A. Cigarette smoking during pregnancy regulates the expression of specific nicotinic acetylcholine receptor (nAChR) subunits in the human placenta. Toxicol Appl Pharmacol. 2014 doi:S0041-008X(14)00060-X [pii]10.1016/j taap.2014.02.015.

41. Hauck Y, Ronchi F, Lourey B, Lewis L. Challenges and enablers to smoking cessation for young pregnant Australian women: a qualitative study. Birth. 2013; 40: 202-8. doi:10.1111/birt.12057.

42. de Leeuw R, Eisenlohr-Moul T, Bertrand P. The association of smoking status with sleep disturbance, psychological functioning, and pain severity in patients with temporomandibular disorders. J Orofac Pain. 2013; 27: 32-41. doi:10.11607/jop.1040.

43. He Y, Jiang B, Li LS, Sun DL, Wu L, Liu M, et al. Changes in Smoking Behavior and Subsequent Mortality Risk During a 35-Year Follow-up of a Cohort in Xi'an, China. Am J Epidemiol. 2014. doi:kwu011 [pii]10.1093/aje/kwu011.

44. Marquez F, Antona MJ, Gomez Vizcaino MT, Cordero Montero P, Chavez Roldan H. Prevalence of Smoking in Women Diagnosed With Sleep Apnea-Hypopnea Syndrome (SAHS) in a University Hospital. Chest. 2014; 145: 614A. doi:10.1378/chest.18216631837296 [pii].

45. Kvalheim S, Sandven I, Hagen K, Zwart JA. Smoking as a risk factor for chronic musculoskeletal complaints is influenced by age. The HUNT study. Pain. 2013; 154: 1073-9. doi:10.1016/j.pain.2013.03.015S0304-3959(13)00110-3 [pii].

46. Joubert BR, Haberg SE, Bell DA, Nilsen RM, Vollset SE, Midttun O, et al. Maternal smoking and DNA methylation in newborns: In utero effect or epigenetic inheritance? Cancer Epidemiol Biomarkers Prev. 2014. doi:1055-9965.EPI-13-1256 [pii]10.1158/1055-9965.EPI-13-1256.

47. Mikkilineni H, Reddy DM, Jayanth N. Effects of smoking on implant failure--a review. J N J Dent Assoc. 2013; 84: 14-5.

48. Ayo-Yusuf OA, Olutola BG. Epidemiological association between osteoporosis and combined smoking and use of snuff among South African women. Niger J Clin Pract. 2014; 17: 174-7. doi:10.4103/1119-3077.127542NigerJClinPract_2014_17_2_174_127542 [pii].

49. Kalucka S. Social aspects of tobacco addiction and the quality of life of people smoking and non-smoking tobacco. Przegl Lek. 2012; 69: 908-13.

50. Jia WP. The impact of cigarette smoking on metabolic syndrome. Biomed Environ Sci. 2013; 26: 947-52. doi:10.3967/bes2013.029.

51. Strong C, Juon HS, Ensminger ME. Long-term Effects of Adolescent Smoking on Depression and Socioeconomic Status in Adulthood in an Urban African American Cohort. J Urban Health. 2013 doi:10.1007/s11524-013-9849-0.

52. Durmus B, Heppe DH, Taal HR, Manniesing R, Raat H, Hofman A, et al. Parental smoking during pregnancy and total and abdominal fat distribution in school-age children: the Generation R Study. Int J Obes (Lond). 2014. doi:10.1038/ijo.2014.9ijo20149 [pii].

53. Sharafutdinova LR, Magzhanov RV, Rakhmatullin AR, Bakhtiiarova KZ. [Smoking as a risk factor of development and progression of multiple sclerosis (a review and experimental data)]. Zh Nevrol Psikhiatr Im S S Korsakova. 2013; 113: 18-22.

54. Stephens BF, Murphy A, Mihalko WM. The effects of nutritional deficiencies, smoking, and systemic disease on orthopaedic outcomes. J Bone Joint Surg Am. 2013; 95: 2152-7.

55. Golda R, Przybylski G, Dokladna W, Pyskir M, Pyskir J. [Analysis of occurrence atypical proteins in the serum at smoking and non-smoking cigarettes patients with lung cancer]. Przegl Lek. 2013; 70: 784-6.

56. Sliwinska-Mosson M, Topola M, Milnerowicz S, Milnerowicz H. [Assessment of concentrations of creatinine, uric acid and urea in non-smoking and smoking patients with chronic pancreatitis]. Przegl Lek. 2013; 70: 809-12.

57. Ekstrom M, Gustafson T, Boman K, Nilsson K, Tornling G, Murgia N, et al. Effects of smoking, gender and occupational exposure on the risk of severe pulmonary fibrosis: a population-based case-control study. BMJ Open. 2014; 4: e004018. doi:10.1136/bmjopen-2013-004018bmjopen-2013-004018 [pii].

58. Vlassopoulos A, Lean ME, Combet E. Influence of smoking and diet on glycated haemoglobin and 'pre-diabetes' categorisation: a cross-sectional analysis. BMC Public Health. 2013; 13: 1013. doi:10.1186/1471-2458-13-10131471-2458-13-1013 [pii].

59. Nagrebetsky A, Brettell R, Roberts N, Farmer A. Smoking cessation in adults with diabetes: a systematic review and meta-analysis of data from randomised controlled trials. BMJ Open. 2014; 4: e004107. doi:10.1136/bmjopen-2013-004107bmjopen-2013-004107 [pii].

60. Henderson SB, Rauch SA, Hystad P, Kosatsky T. Differences in lung cancer mortality trends from 1986-2012 by radon risk areas in british columbia, $\begin{array}{llll}\text { Canada. Health Phys. 2014; 106: 608-13. } & \end{array}$ doi:10.1097/HP.000000000000000500004032-201405000-00010 [pii].
61. Dijkstra AE, de Jong K, Boezen HM, Kromhout H, Vermeulen R, Groen HJ, et al. Risk factors for chronic mucus hypersecretion in individuals with and without COPD: influence of smoking and job exposure on CMH. Occup Environ Med. 2014. doi:10.1136/oemed-2013-101654oemed-2013-101654 [pii].

62. Braganza MZ, Rajaraman P, Park Y, Inskip PD, Freedman ND, Hollenbeck AR, et al. Cigarette smoking, alcohol intake, and risk of glioma in the NIH-AARP Diet and Health Study. Br J Cancer. 2014; 110: 242-8. doi:10.1038/bjc.2013.611bjc2013611 [pii].

63. Peres J. No clear link between passive smoking and lung cancer. J Natl Cancer Inst. 2013; 105: 1844-6. doi:10.1093/jnci/djt365djt365 [pii].

64. Ben Saad H, Khemiss M, Nhari S, Ben Essghaier M, Rouatbi S. Pulmonary functions of narghile smokers compared to cigarette smokers: a case-control study. Libyan J Med. 2013; 8: 22650. doi:10.3402/ljm.v8i0.2265022650 [pii].

65. Jiloha RC. Pharmacotherapy of smoking cessation. Indian J Psychiatry. 2014; 56: 87-95. doi:10.4103/0019-5545.124726IJPsy-56-87 [pii]

66. Smith PH, Homish GG, Giovino GA, Kozlowski LT. Cigarette smoking and mental illness: a study of nicotine withdrawal. Am J Public Health. 2014; 104: e127-33. doi:10.2105/AJPH.2013.301502.

67. Ramakrishna R, Rostomily R, Rockhill J. A rare case of gamma knife-induced smoking cessation in a patient with a vestibular schwannoma. Br J Neurosurg. 2013; 27: 251-2. doi:10.3109/02688697.2012.725873.

68. Kato T, Umeda A, Miyagawa K, Takeda H, Adachi T, Toyoda S, et al. Varenicline-assisted smoking cessation decreases oxidative stress and restores endothelial function. Hypertens Res. 2014. doi:10.1038/hr.2014.52hr201452 [pii].

69. David SP, Chu IM, Lancaster T, Stead LF, Evins AE, Prochaska JJ. Systematic review and meta-analysis of opioid antagonists for smoking cessation. BMJ Open. 2014; 4: e004393. doi:10.1136/bmjopen-2013-004393.

70. Agahi N, Shaw BA. Smoking trajectories from midlife to old age and the development of non-life-threatening health problems: a 34-year prospective $\begin{array}{lllll}\text { cohort study. Prev } & \text { Med. 2013; 57: }\end{array}$ doi:10.1016/j.ypmed.2013.04.016S0091-7435(13)00125-4 [pii]. 